\title{
The Influence of Financial Ratios on Share Prices (Case Studies on Property \& Realestate Companies in the Construction and Building Sub-Sector Listed on the Indonesia Stock Exchange)
}

\author{
Herlina Dwiyanthi*, Neneng Faridatul Husna, Wili Handayani \\ Nusa Putra University, Indonesia
}

*Corresponding author:

E-mail:

herlina.dwiyanthi_ak18@nusapu-

tra.ac.id

\begin{abstract}
This study aims to determine the effect of financial ratios on stock prices in property real estate companies in the construction and building sector listed on the Indonesia Stock Exchange (IDX) for the 2016-2019 period. By using the ratio of profitability, liquidity, and solvency. The financial ratios studied are Current Ratio (CR), Return on Assets (ROA), Return on Equity (ROE), Net Profit Margin (NPM), and Operating Profit Margin (OPM), as independent variables and stock prices as the dependent variable. In this study, researchers used as many as 8 sample companies. The data used are quantitative data on the annual financial statements of companies listed on the Indonesian stock exchange (BEI). This study uses multiple linear regression analysis using the SPSS program.
\end{abstract}

Keywords: Current Ratio (CR), Return on Asset (ROA), Return on Equity (ROE), Net Profit Margin (NPM), and Operating Profit Margin (OPM), and Share Price

\section{Introduction}

In this era of globalization where there are many opportunities for people to invest, not a few people make this investment an alternative way of investing in the future. Investments can generally be made in real assets (land, gold, or business) or financial assets (deposits, stocks, or bonds). Investing in stocks in the capital market is an alternative that investors can invest in investing their funds in financial assets. The capital market in Indonesia has also encouraged go public companies to sell part of their shares to the public.

The shares of a company can attract many investors if the company can achieve good performance. To assess the financial performance and achievements of a company, an investor needs financial statement analysis as a consideration in determining stock prices. Financial statement analysis requires several benchmarks in assessing the company's financial condition. . One of the benchmarks that are often used is the ratio or index, which connects two financial data (Ahmad et al., 2018). The objective of investors investing in stocks in the capital market is to find the highest return on investment (return) in the future.

Argues that return is one of the factors that motivates investors to interact and is also a reward for investors' courage in taking risks for their investment. In short, return is the profit that investors get from funds invested in an investment. One of the aspects assessed by investors in their investment is financial performance. In principle, the better the company's financial performance, the more demand for the company's shares will increase, thus increasing the company's stock price (Milosevic-Avdalovic \& Milenkovic, 2017).

The uncertainty factor in predicting stock prices is an important problem for investors because stock prices always change or are volatile. Therefore, we need a tool to predict or predict the stock price of any company that will provide benefits so as not to make the wrong choice. (Raharjo \& Muid, 2013)

\section{How to cite:}

Dwiyanthi, H., Husna, N. F., \& Handayani, W. (2021). The influence of financial ratios on share prices (Case studies on property \& realestate companies in the construction and building sub-sector listed on the indonesia stock exchange). $1^{\text {st }}$ ICEMAC 2020: International Conference on Economics, Management, and Accounting. NST Proceedings. pages $412-424$. doi: $10.11594 /$ nstp.2021.1046 
According to Munawir (2004) Ratio analysis is a tool used to help analyze a company's financial statements so that a company's strengths and weaknesses can be identified. Ratio analysis also provides indicators that can measure the level of profitability, liquidity, income, utilization of company assets and liabilities (Pratama \& Erawati, 2016)

Financial ratios in the financial statements reflect company performance. Company performance affects the company's stock price. In this study, the ratios used are Current Ratio (CR), Return on Asset (ROA), Return on Equity (ROE), Net Profit Margin. (NPM), and Operating Profit Margin (OPM). The samples of this study come from real estate property companies, the building construction sector on the Indonesia Stock Exchange, the analysis period is 4 years 2016-2019.

Based on the above background, the problem formulations in this study are as follows:

1. Does the Current Ratio (CR) affect the stock price of real estate property companies in the building construction sector?

2. Does Return on Asset (ROA) affect the stock price of property real estate companies in the building construction sector?

3. Does Return on Equity (ROE) affect the stock price of property real estate companies in the building construction sector?

4. Does Net Profit Margin (NPM) affect the stock price of real estate property companies in the building construction sector?

5. Does Operating Profit Margin (OPM) affect the stock price of real estate property companies in the building construction sector?

Research Objectives and Uses

1. Knowing the effect of financial ratios on stock prices for property real estate companies in the building construction sector for the last four years for the 2016-2019 period

2. Provides information on financial ratios that affect stock prices for real estate property companies in the building construction sector and provides information about the significant changes in each of the financial ratio variables studied from year to year for the 2016-2019 period.

\section{Literature Review}

\section{Theory basis}

\section{Financial statements}

Financial reports are records of a company's financial information in a certain accounting period that can be used to describe the company's performance and to provide information to those who need financial reports.

According to Szydelko and Biadacz (2016) "Financial statements are the result of an accounting process which includes two main reports, namely: 1. Balance and (2) Income Statement. Every company has a financial report that aims to provide information regarding the financial position, performance, and changes in the financial position of a company that is useful for a large number of users of financial statements in making economic decisions. The FASB concluded that the objectives of financial reporting are to provide information that:

1. Useful for those making investment and credit decisions.

2. Assist in forecasting future cash flows.

3. Identify economic resources (assets), claims on these resources (liabilities), and changes to these resources and other resources.

The Indonesian Institute of Accountants (2012: 5) states the definition of financial statements, namely financial statements are structures that present the financial position and financial performance in an entity. The general purpose of these financial statements for the public interest is the presentation of information on the financial position, financial performance. (financial performance), and cash flow (cash flow) from the entity which is very useful for making economic decisions for its users. To achieve this goal, financial statements provide information about the elements of the entity consisting of assets, 
liabilities, net worth, expenses, and income (including gains and losses), changes in equity and cash flows. The information, followed by notes, will help users predict future cash flows (Munawir, 2010).

\section{Stock price}

The definition of the share price is "The price of a share that occurs on the stock market at a certain time which is determined by market players and is determined by the demand and supply of shares in the stock market"

According to Lipovetski and Magnan (2011), share prices are defined as follows: "Prices on the real market and are the easiest prices to determine because they are the price of a share in the ongoing market or if the market is closed, the market price is the closing price. ".

Based on the experts above, it can be concluded that the stock price is the closing price of the stock market during a certain period, the stock price is formed by market players and is determined by the demand and supply of shares in the stock buying and selling market or in the capital market. Share prices can also change up to or down. in a matter of time so fast due to changing market demand and supply.

\section{Returns On Equity (ROE)}

Return On Equity is a ratio that measures the effectiveness or ability of the company in managing capital from investors to get net income. According to Rosikah et al. (2018), this ratio is the most important because shareholders certainly want to get a high rate of return on the capital they invest and ROE shows the rate they earn. In general, of course, the higher the return or income obtained, the better the position of the owner of the company, the higher the ROE, which means the better the company's performance in managing the capital it has to generate profits for the company owner. The more able the company is to provide benefits for shareholders, the greater the interest of investors to buy shares in the company.

Return On Equity formula:

Return On Equity $=\frac{\text { Net profit }}{\text { Total Capital }} \times 100 \%$

\section{Return On Asset (ROA)}

Return On Asset (ROA) is a ratio used to measure the rate of return on investment that the company has made using all the funds (assets) it owns. Therefore, the greater the ROA of a company, the greater the profit generated, it will attract investors to buy shares in the company so that the company's stock price will increase (Ahmad et al., 2018)

Return On Asset Formula:

Return On Asset $=\frac{\text { Net profit }}{\text { Total Assets }} \times 100 \%$

\section{Current Ratio (CR)}

According to Hantono (2018) explaining the current ratio is the ratio that compares the assets owned by the company with short-term debt. Meanwhile, according to Durrah et al. (2016), the current ratio is the most common in measuring the level of liquidity of a company. The higher the current rate, the more capable the company is to pay off its current obligations.

Current Ratio formula:

$$
\text { Current Ratio }=\frac{\text { Current asset }}{\text { Current liabilities }} \times 100 \%
$$


Net profit margin (NPM)

Net profit margin (NPM) is the relationship between net profit after tax and sales showing the ability of management to run the company until it is quite successful in restoring/controlling the cost of goods/services, operating expenses, depreciation, loan interest, and taxes.

Net profit margin formula:

Net Profit Margin $=\frac{\text { net profit after tax }}{\text { Sales }}$

Operating Profit Margin (OPM)

According to Manglik and Goyal (2016), Operating profit margin is a comparison between operating profit and sales. The operating profit margin is a ratio that describes what is usually called the pure profit received for every dollar of sales made.

Operating Profit Margin Formulas:

Operating Profit Margin $=\frac{\text { Net Profit Before Tax }}{\text { Sales }}$

\section{Conceptual framework}

Based on literature review, concepts from previous research, a conceptual framework can be drawn up as follows:

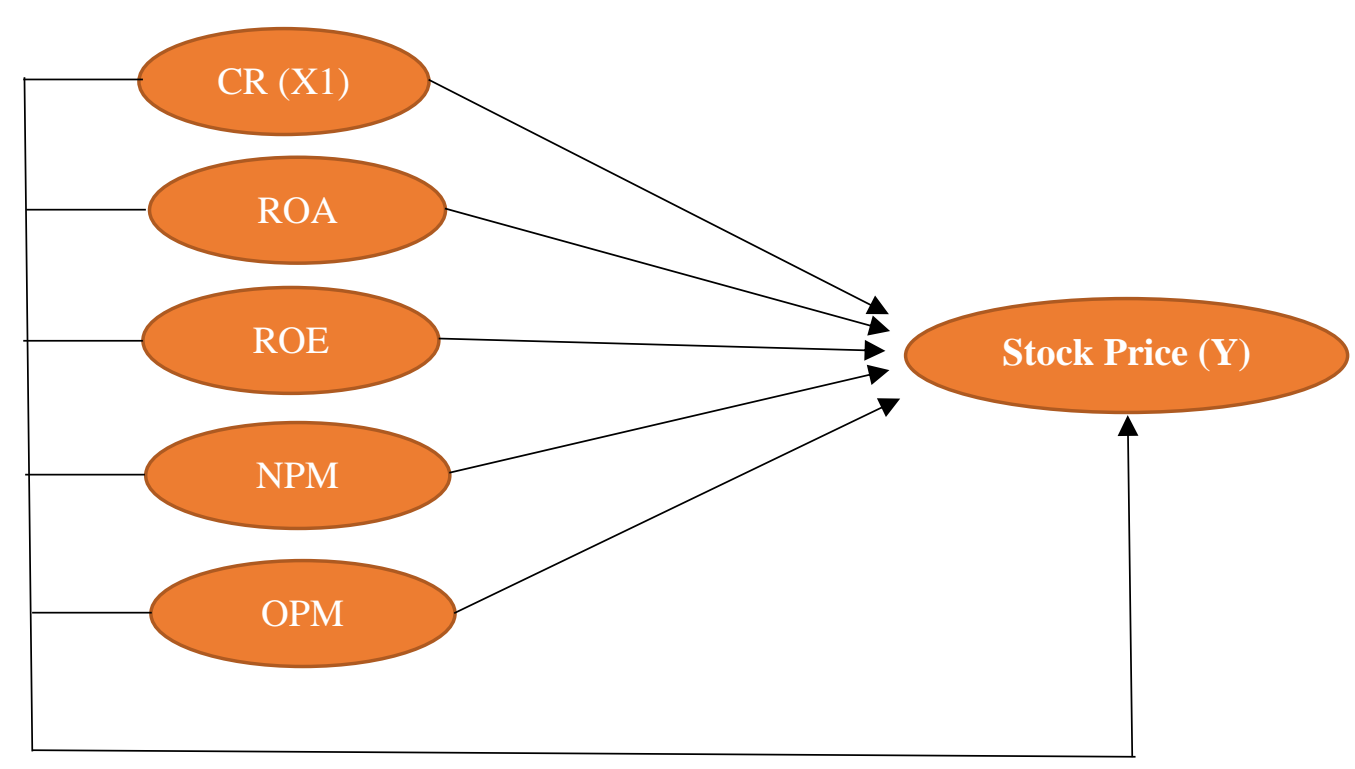

Figure 1. The concepts of previous research

\section{Hypothesis}

Sugiono explained that the hypothesis is a temporary answer to the formulation of research problems, where the formulation of the research problem has been stated in the form of a question sentence. Based on the formulation of the problem described above, the hypothesis is proposed as follows: 
The influence of the Current Ratio (CR) on stock prices

The current Ratio (CR) shows the level of the company's ability to pay short-term debts. There is no absolute stipulation on how many CR levels are considered good or should be maintained by a company because usually this CR level also depends on the type of business of each company (Dichevska et al., 2016).

From the results of research conducted by Octaviani and Komalasari (2017), the current ratio (CR) has a significant effect on stock prices.

\section{H1: Current Ratio (CR) affects stock prices}

The effect of return on Assets (ROA) on stock prices

Return on Asset (ROA) What is often called return on investment is a measure of the company's overall ability to generate profits with the total number of assets available in the company. The greater the ROA, the greater the level of profit achieved by the company and shows that management can use the company's total assets properly so that it will increase the company's stock price and can attract many investors to invest in the company (Manoppo, 2015).

\section{H2: Return on Asset (ROA) affects stock prices}

The effect of Return on Equity (ROE) on stock prices

Returns on Equity (ROE) is a ratio that reflects the success of a company. A high ROE will attract the attention of investors and investors will pursue the company. So, the higher the ROE, the better the company's performance in managing the capital owned to generate profits for the owner of the company.

The results of research conducted by Pratama \& Erawati (2016), show that Return on Equity (ROE) has a positive and significant effect on stock prices.

\section{H3: Return on Equity (ROE) affects stock prices}

The effect of Net Profit Margin (NPM) on stock prices

Net Profit Margin (NPM) is a measure of profit that compares profit after interest and tax compared to sales (Heikal et al., 2014). The greater the NPM number, the company will be considered good because it can generate high profits. NPM affects stock prices, the higher the NPM, the stock price will also increase.

\section{H4: Net Profit Margin (NPM) affects stock prices}

\section{The effect of Operating Profit Margin (OPM) on stock prices}

Bustani (2020) states that without profit, the company will not attract investors, so the OPM ratio is important for investors to start the company's future. A good OPM is one with a high ratio, this means that the company can operate with high efficiency and can reduce the company's cost structure so that it can have the ability to compete in the selling price of its products. This means that the company has a good performance to be used as investment land.

And the results of his research show that Operating Profit Margin (OPM) has a positive and significant effect on stock prices.

\section{H5: Operation Profit Margin (OPM) affects stock prices}




\section{Research Methods \\ Types of research}

The data collection method used in this research is the quantitative method, namely data that is expressed in numbers, with the object of research being the annual financial statements of building construction sector companies listed on the Indonesia Stock Exchange. This study takes an analysis period from 2016 to 2019. The data used are secondary data obtained from the Indonesia Stock Exchange. Secondary data are sources that are obtained indirectly (obtained and recorded by other parties). The data used are financial statement data. And the stock price used is the closing price of the company's year-end shares as of December 31.

The dependent variable in this study is stock prices, while the independent variable is financial ratios. The financial ratios used are CR (Current Ratio), ROA (Return of Assets), ROE (Return Of Equity), NPM (Net Profit Margin), OPM (Operating Margin). Testing the effect of financial ratios on manufacturing stock prices contained in the Indonesia Stock Exchange. Data analysis by testing classical assumptions, normality test, multicollinearity test, heteroscedasticity test, autocorrelation test, determining regression model formulations, and testing hypotheses.

\section{Population and Sample}

According to Sugiyono (2011) population is a generalization area consisting of objects or subjects that have certain qualities and characteristics that are determined by researchers to be studied and then draw conclusions. In this study, the authors will take the population of construction and building companies listed on the IDX for the 2016-2019 period.

Samples are some elements of the population (Datta, 2018). In the research, the researcher will use the purposive sampling technique, where the sample is taken based on certain criteria according to the research objectives which are considered to represent the research. The sample selection criteria studied were as follows:

a. Construction and building companies listed on the IDX in the 2016-2019 period

b. Construction and building companies that publish complete financial reports for the years 20162019.

c. Construction and building companies that did not experience losses in the 2016-2019 period.

Based on these criteria, from a total population of 10 construction and building companies, there were 8 companies with an observation period of 4 years, from 2016-2019, so that the number of sample companies observed was 32 company financial reports.

\section{Operational variables}

Operational Variables Research variables consisting of five independent variables and one dependent variable are presented in the following table:

\section{Descriptive statistics}

Descriptive statistics are statistics that are used to analyze data by describing or describing data that has been gathered as it is without intending to make general conclusions or generalizations (Sugiyono, 2011). Before analyzing the data with others, the writer will first describe or present the data based on the mean, minimum, and maximum values. 
Table 1. Sample list

\begin{tabular}{cll}
\hline NO & \multicolumn{1}{c}{ Stock code } & \multicolumn{1}{c}{ Issuer Name } \\
\hline 1 & ACST & Acset Indonusa Tbk \\
2 & ADHI & Adhi Karya (Persero) Tbk \\
3 & NRCA & Nusa Raya Cipta tbk \\
4 & PTPP & Housing Development (Persero) Tbk \\
5 & PBSA & Paramita Bangun Saran Tbk \\
6 & IDPR & Indonesia Pondasi Raya Tbk \\
7 & CSIS & Cahaya Sakti Investindo Sukses Tbk \\
8 & PSSI & Pelita Samudera Shipping Tbk \\
\hline
\end{tabular}

Results and Discussion

Research Result

Descriptive statistics

Table 2. Descriptive statistics results

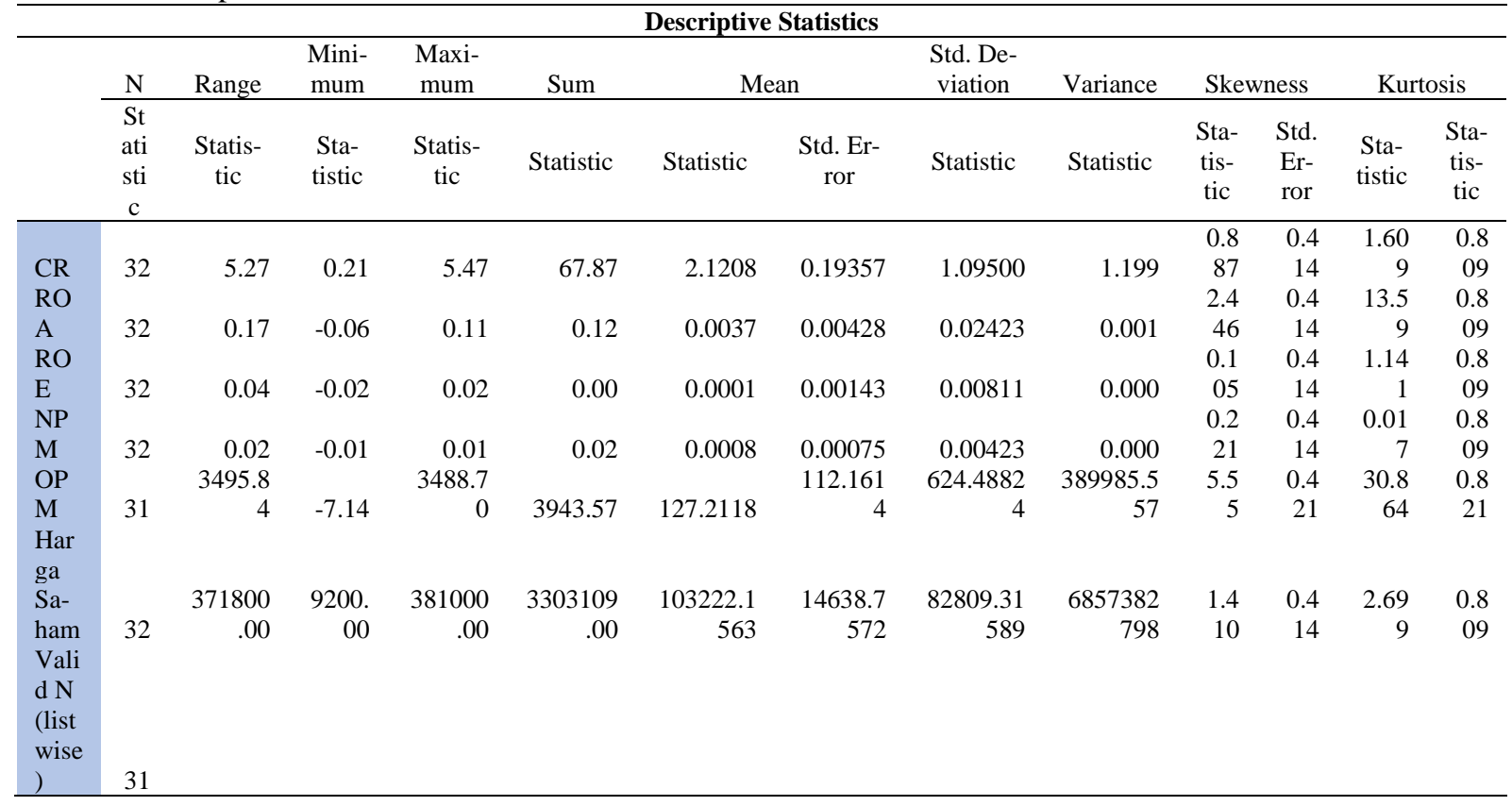

Based on the table above, shows the amount of data used in this study as many as 32 samples studied during the 2016-2019 period. Based on the results of the above calculations, it appears that the lowest CR value is $0.21 \%$, and the highest CR value is 5.47 with an average CR value of 2.1208 and a standard deviation of 1.09500 . The ROA variable has a minimum value of -0.06 , and the highest ROA value is 0.11 with an average value of 0.0037 and a standard deviation of 0.02423 . The ROE variable has a minimum value of -0.02 and a maximum value of 0.02 with an average value of 0.0001 and a standard deviation of 0.00811 . The NPM variable has a minimum value of -0.01 and a maximum value of 0.01 with an average value of 0.0008 and a standard deviation of 0.00423 . The OPM variable has a minimum value of -7.14 and a maximum value of 3488,70 with an average value of 127.2118 and a standard deviation of 624.48824. The Variable Share Price has a minimum value of 9200.00 and a maximum value of 381000.00 with an average value of 103222.1563 and a standard deviation of 82809.31589. 


\section{Normality test}

Table 3. Normality test results One-Sample Kolmogorov-Smirnov

\begin{tabular}{|c|c|c|c|}
\hline & & Unstandardi & dual \\
\hline $\mathrm{N}$ & & & 31 \\
\hline Normal & Mean & & 0.0000000 \\
\hline Parameters ${ }^{\mathrm{a}, \mathrm{b}}$ & $\begin{array}{l}\text { Std. } \\
\text { Deviation }\end{array}$ & 67870.52758506 & \\
\hline & Absolute & & 0.077 \\
\hline Most Extreme Differences & Positive & & 0.077 \\
\hline & Negative & & -0.061 \\
\hline Test Statistic & & & 0.077 \\
\hline Asymp. Sig (2Tailed) & & & $.200^{\mathrm{c}, \mathrm{d}}$ \\
\hline a. Test distribution is Norm & & & \\
\hline b. Calculated from data. & & & \\
\hline c. Lilliefors Significance C & & & \\
\hline d. This is a lower bound of & significan & & \\
\hline
\end{tabular}

In the table above, it can be seen that the Kolmogorov-Smirnov value is 0.077 with a significance level far above 0.05 , namely 0.200 , which means that the residual variables are normally distributed. Through the results of the uni normality carried out, it can be concluded overall that the observed data values have been normally distributed and can be continued with other classical assumption tests.

\section{Results of multiple linear regression analysis}

Table 4. Results of multiple linear regression analysis

\section{Coefficients $^{\mathrm{a}}$}

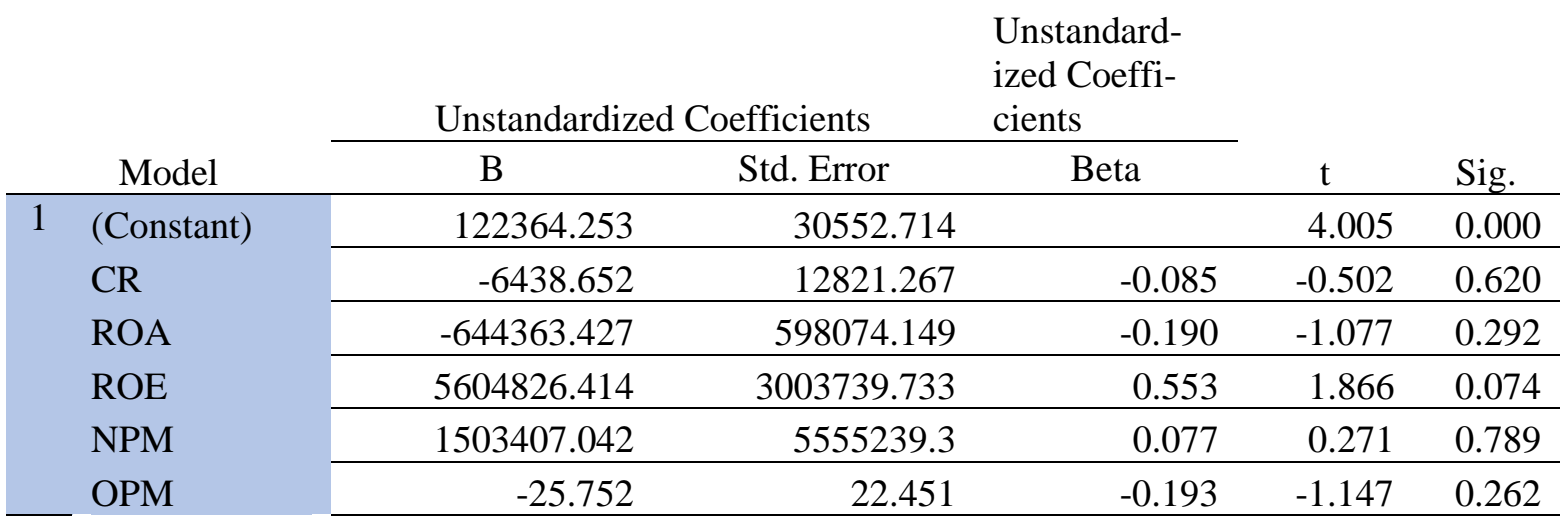

a. Dependend Variable: Stock price

From the regression calculations above, the regression equation can be drawn up as follows:

$\mathrm{Y}=122364,253-6438,652 \mathrm{CR}-644363,427 \mathrm{ROA}+5604826,414 \mathrm{ROE}+1503407,042 \mathrm{NPM}-25,752$ OPM 
The regression transformation equation above has the following meanings:

1. The constant-coefficient is 122364,253 which shows the stock price is 122364,253 if each of the CR, ROA, ROE, NPM, and OPM variables is 0 . The positive constant-coefficient value shows that financial performance tends to increase.

2. Regression coefficient $\mathrm{X} 1$ or the CR variable is - 6438,652 , this shows that if every $1 \%$ increase in the CR variable, while the ROA, ROE, NPM, and OPM variables are assumed to be fixed, the share price will decrease by - 6438,652

3. Regression coefficient X2 or the ROA variable of $-644363,427$, shows that every $1 \%$ increase in the ROA variable, while the CR, ROE, NPM, and OPM variables are assumed to be fixed, the share price will decrease by $-644363,427$

4. Regression variable X3 or the ROE variable of 5604826,414, shows that if every $1 \%$ increase in the ROE variable, while the CR, ROA, NPM, and OPM variables are assumed to be fixed, then the share price will increase by 5604826,414.

5. Regression variable X4 or the NPM variable is 1503407,042 , this shows that if every $1 \%$ increase in the NPM variable, while the CR, ROA, ROE, and OPM variables are assumed to be fixed, the share price will increase by 1503407,042

6. Regression variable $\mathrm{X} 5$ or the OPM variable is $-25,752$, this shows that if every $1 \%$ increase in the OPM variable, while the CR, ROA, ROE, and NPM variables are assumed to be trap, the share price will increase by $-25,752$

\section{Hypothesis testing results}

T-test (Partial test)

Table 5. T-test results (Partial test)

\section{Coefficients $^{\mathrm{a}}$}

\begin{tabular}{|c|c|c|c|c|c|c|}
\hline \multirow{2}{*}{\multicolumn{2}{|c|}{ Model }} & \multicolumn{2}{|c|}{ Unstandardized Coefficients } & \multicolumn{3}{|l|}{$\begin{array}{l}\text { Unstandard- } \\
\text { ized Coeffi- } \\
\text { cients }\end{array}$} \\
\hline & & B & Std. Error & Beta & $\mathrm{t}$ & Sig. \\
\hline 1 & (Constant) & 122364.253 & 30552.714 & & 4.005 & 0.000 \\
\hline & CR & -6438.652 & 12821.267 & -0.085 & -0.502 & 0.620 \\
\hline & ROA & -644363.427 & 598074.149 & -0.190 & -1.077 & 0.292 \\
\hline & ROE & 5604826.414 & 3003739.733 & 0.553 & 1.866 & 0.074 \\
\hline & NPM & 1503407.042 & 5555239.3 & 0.077 & 0.271 & 0.789 \\
\hline & OPM & -25.752 & 22.451 & -0.193 & -1.147 & 0.262 \\
\hline
\end{tabular}

a. Dependend Variable: Stock price

Based on the results of the SPSS test above, can be seen the level of influence of CR, ROA, ROE, NPM, and OPM on stock prices as follows:

1. The effect of CR on stock prices

Based on the SPSS calculation, the $t$-count is -0.502 with a significant value of 0.620 and the $t$ table is 2.060 , because $t$ count $<t$ table $(-0.502<2.060)$ and the significant value is greater than 0.05 (0.620>0.05), it can be concluded that CR affects positive and insignificant to the stock price.

2. Effect of ROA on stock prices

Based on the SPSS calculation, the t-count is -1.077 with a significant value of 0.292 and the $t$ table is 2.060 , because $t$ count $<\mathrm{t}$ table $(-1.077<2.060)$ and the significant value is greater than 0.05 (0.292> 0.05), it can be concluded that CR affects negative and significant to the Share Price. 
3. Effect of ROE on stock prices

Based on the SPSS calculation, the t-count is 1.866 with a significant value of 0.074 and a ttable of 2.060. Because $t$ count $<\mathrm{t}$ table $(1.866<2.060)$ and the significant value is greater than 0.05 (0.074>0.05), it can be concluded that CR has a negative effect and significant on the Share Price.

4. The Effect of NPM on stock prices

Based on the SPSS calculation, the t-count is 0.271 with a significant value of 0.789 and the ttanel is 2.060 . Because $t$ count $<\mathrm{t}$ table $(0.271<2.060)$ and the significant value is greater than 0.05 (0.789> 0.05), it can be concluded that CR has a positive effect and not significant on the Share Price.

5. The Effect of OPM on stock prices

Based on the SPSS calculation, the t-count is -1.147 with a significant value of 0.262 and t-tanel of 2.060 . Because $t$ count $<t$ table $(-1.147<2.060)$ and the significant value is greater than 0.05 (0.262>0.05), it can be concluded that CR affects positive and insignificant to the stock price.

F-test (Simultaneous test)

Table 6. F-test result (Simultaneous test)

\begin{tabular}{|c|c|c|c|c|c|c|}
\hline \multicolumn{7}{|c|}{ ANOVA $^{a}$} \\
\hline \multicolumn{2}{|c|}{ Model } & Sum of Squares & $\mathrm{df}$ & Mean Square & $\mathrm{F}$ & Sig. \\
\hline \multirow[t]{3}{*}{1} & Regression & 71123714929 & 2 & 14224742986 & 2.573 & $.052^{\mathrm{b}}$ \\
\hline & Residual & 138192255440.247 & 25 & 5527690218 & & \\
\hline & Total & 209315970369.419 & 30 & & & \\
\hline
\end{tabular}

a. Dependent Variable: Stock price

b. Predictors: (Constant), OPM, CR, ROA, NPM, ROE

From the results of the regression analysis, it can be seen that together (simultaneously) the independent variables have a significant effect on the dependent variable. This can be proven from the calculated $\mathrm{F}$ value of 2.573 and the $\mathrm{F}$ table value of 2.60 with a probability of 0.052 . Because the calculated $\mathrm{F}$ value is smaller than F-table $(2.573<2.60)$ and the significant value is less than 0.05 or $5 \%$, the regression model can be used to predict the Stock Price or it can be said that CR, ROA, ROE, NPM, and OPM together has a significant effect on stock prices.

\section{Determination coefficient Test (R2)}

Table 7. Determination coefficient test results

\begin{tabular}{lcccr}
\hline Model & $\mathrm{R}$ & R Square & \multicolumn{2}{c}{ Model Summary } \\
Adjusted R Square & Std. Error of the Estimate \\
1 & $.583^{\text {a }}$ & 0.34 & 0.208 & 74348.4379 \\
a. Predictors: (Constant), OPM, CR, ROA, NPM, ROE & & \\
\multicolumn{2}{l}{ b. Dependent Variable: Stock price } & & \\
\hline
\end{tabular}

The table above shows the amount of adjusted R2 of 0.208 , this means that $20.8 \%$ of the variation in financial performance (share price) can be explained by variations of the 5 independent variables CR, ROA, ROE, NPM, and OPM. While the rest $(100 \%-20.8 \%=79.2 \%)$ is explained by other variables outside the research.

\section{Discussion}

This section will present a discussion of the results of the analysis that has been carried out. The results of the analysis are described as follows: 
1. The Effect of CR on Stock Prices

The research results obtained the CR coefficient of $-6438,652$ with a significant value of 0.620 . This shows that CR does not affect Share Price, so it can be concluded that H1 is rejected and H0 is accepted. This means that partially it does not affect the stock price. The liquidity ratio shows the extent to which current assets cover current liabilities. The greater the ratio of current assets to current debt, the higher the company's ability to cover its short-term liabilities, if the company is believed to be able to pay off its current liabilities. In short, the company is in good condition and can increase the stock price because investors are interested in the company's financial condition like this.

Thus, if the company's liquidity ability is good, investors do not need to worry about whether the capital they invest in the company will return and provide benefits for them or not. This is because a company whose liquidity level is not good tends to be shunned by investors. After all, they are afraid that the funds they invested will not return and result in losses for investors. This is consistent with research conducted by Achmad Syaiful Susanto (2011) which in his research shows that CR (Liquidity) has no significant effect on stock prices.

2. Effect of ROA on Stock Prices

The ROA coefficient is obtained at $-644363,427$ with a significance value of-1.077, which means less than 0.10 , then $\mathrm{Ha} 2$ is accepted. This shows that ROA has a significant effect on stock prices. ROA (Return on Asset) shows the company's ability to generate profits from the assets used. ROA is obtained from the ratio between earning after taxes and total assets. Thus the higher the ROA of a company, the higher the value of the company's assets and causes the stock price to be higher because it is in great demand by investors. This can be because if the company can make a good profit or profit every period, investors do not need to worry about the company will lose out or even bankrupt. Thus, the profit or profit the company gets can also be enjoyed by investors and opens up the possibility of new investors who want to invest their capital there

which can increase the market price of the company's stock. This is consistent with research conducted by Dr. Majed Abdel Majid Kabejah, Dr. Said Mukhled Ahmed AL Nu'aimat, and Dr. Firas Naim Dahmash (2012) who in his research showed that ROA (Profitability) has a significant effect on stock prices.

3. Effect of ROE on Stock Prices

The research results obtained an ROE coefficient of 5604826,414 with a significant value of 1,866 . This shows that ROE does not affect share prices. The solvency ratio is the ratio to assess the company's ability to pay all its obligations, both short and long term if the company is dissolved. The higher the solvency. companies must as much as possible increase their profits to be able to finance and pay debts.

\section{The Effect of NPM on Stock Prices}

In the results above, the NPM coefficient is obtained for 1503407,042 with a significant value of 0.789. This shows that NPM influences the stock price because the value meets standard criteria, which means the level of profit the company receives from the main operating activities of a large company.

5. The Effect of OPM on Stock Prices

In the results above, the OPM coefficient is obtained for $-25,752$ with a significant value of 1,147 . This shows that OPM does not have a significant effect on the company's stock price. This suggests that other factors affect the company's stock price.

The influence of CR, ROA, ROE, NPM, and OPM on Stock Prices simultaneously. The fourth hypothesis states that CR, ROA, ROE, NPM, and OPM simultaneously influence stock prices. Based on the F test, it can be seen that simultaneously the independent variable has a significant effect on the independent variable. This is evidenced by the calculated $\mathrm{F}$ value of $2.537 \%$ with a significance 
of 0.052. So, it is concluded that the independent variables (CR, ROA, ROE, NPM, and OPM) simultaneously influence (jointly) the dependent variable Stock Price.

\section{Conclusion}

This study examines whether CR, ROA, ROE, NPM, and OPM can affect stock prices in companies. The results of hypothesis testing using multiple linear regression with five independent variables (CR, ROA, ROE, NPM, and OPM) and one dependent variable (Stock Price), indicate that:

1. The current ratio (CR) has no significant effect on stock prices. This is consistent with research conducted by several previous researchers who in their research showed that CR has no significant effect on stock prices.

2. Return on Assets (ROA) has a significant effect on stock prices, this is the same in several other studies which show the results that ROA has a significant effect on stock prices.

3. Return on Equity (ROE) has a significant effect on stock prices, this is the same in several other studies which have shown that ROE has a significant effect on stock prices.

4. Net Profit Margin (NPM) has no significant effect on stock prices. This is consistent with research conducted by several previous researchers who in their research showed that NPM had no significant effect on stock prices.

5. Operating Profit Margin (OPM) does not have a significant effect on stock prices, this is the same in several other studies which have shown that OPM has no significant effect on stock prices.

\section{Acknowledgment}

We would like to thank all those who have helped to complete this article.

\section{References}

Ahmad, I., Noholo, S., \& Mahmud, M. (2018). the influence of financial ratios on stock prices in service companies listed in the lq45 index on the indonesia stock exchange (BEI) 2012-2016. Journal of Accounting Insights and Research, 5 (2), 127-138.

Bustani. (2020). The effect of Return on Assets (ROA), Net Profit Margin (NPM), Dividend Payout Ratio (DPR) and Dividend Yield (DY) on stock prices in the subsectors tnsurance company listed in Indonesia stock exchange period 2015-2018. International Journal of Tax Economics and Management, 1(3), 170-178

Datta, S. (2018). Sampling methods. Bio-Statistics \& Computer Application. DOI:10.13140/RG.2.2.22856.57605

Dichevska, S., Nikolovski, P., Karadjova, V., Zdravkoski, I., \& Menkinoski, G. (2016). Strategic alliances and innovations in the international business. International Journal of Sciences: Basic and Applied Research (IJSBAR), 27(1), 57-64.

Durrah, O., Rahman, A. A. A., Jamil, S. A., \& Ghafeer, N. A. (2016). Exploring the relationship between liquidity ratios and indicators of financial performance: an analytical study on food industrial companies listed in Amman Bursa. International Journal of Economics and Financial Issues, 6(2), 435-441

Hantono. (2018). The effect of current ratio, debt to equity ratio, toward return on assets (Case study on consumer goods company). Accountability, 7(02), 64. Doi:10.32400/ja.24804.7.02.2018.64-73

Heilka, M., Khaddafi, M., \& Ummah, A. (2014). Influence analysis of Return on Assets (ROA), Return on Equity (ROE), Net Profit Margin (NPM), Debt to Equity Ratio (DER), and current ratio (CR), against corporate profit growth in automotive in Indonesia Stock Exchange. International Journal of Academic Research in Business and Social Sciences, 4(12), 1-5.

LIpovetsky, S., \& Magnan, S. (2011). Pricing models in marketing research. Intelligent Information Management, 3(05), 167-174. DOI: 10.4236/iim.2011.35020

Manoppo, C. P. (2015). The influence of ROA, ROE, ROS, and EPS on stock price. Jurnal EMBA, 3(4), 691-697.

Milosevic-Avdalovic, S., \& Milenkovic, I. (2017). Impact of company performances on the stock price: An empirical analysis on select companies in Serbia. Ekonomika Poljoprivrede, 64(2), 561-570. Doi:10.5937/ekoPolj1702561M

Manglik, M., \& Goyal, A. (2016). Operating margin ratio (A comparatice study of selected public and private sector companies). Indian Journal of Research, 5(5), 134.

Munawir. (2010). Financial statement theory. Journal of Financial Management, 20-54. 
Pratama, A., \& Erawati, T. (2016). The effect of current ratio, debt to equity ratio, return on equity, net profit margin and earning per share on share prices (Case Study in Manufacturing Companies Listed on the Indonesia Stock Exchange 2008-2011 Period). Journal of Accounting, 2 (1), 1-9. https://doi.org/10.24964/ja.v2i1.20

Raharjo, D., \& Muid, D. (2013). Analysis of the influence of fundamental factors of financial ratios on changes in stock prices. Diponegoro Journal of Accounting, 2(2), 444-454.

Rosikah, Prananingrum, D. K., Muthalib, D. A., Azis, M. I., \& Rohansyah, M. (2018). Effect of return on asset, return on equity, earning per share on corporate value. The International Journal of Engineering and Science, 7(3), 06-14.

Sugiyono. (2011). Quantitative qualitative research methods and R \& D. Alfabeta

Szydelko, A., \& Biadacz, R. (2016). The role of financial statement in performance management. Modern Management Review, 23(2016), 205-214. 